\title{
DEVELOPMENT ONLINE LEARNING SYSTEM FOR SME AND COMMUNITY
}

\author{
Arief A. SUKMANDHANI ${ }^{1}$, Ari YUNIARSO ${ }^{2}$, Siti MARYAM ${ }^{3}$ \\ ${ }^{1}$ Binus Online Learning, Computer Science, Indonesia \\ ${ }^{2}$ Department of Hotel Management, Indonesia \\ ${ }^{3}$ School of Information Systems, Indonesia \\ *arief.sukmandhani@binus.ac.id
}

\begin{abstract}
The more rapid development of technology has an impact on learning methods. In the past, learning was only done traditionally, namely face-to-face, now the learning method can be done through online media, namely through internet intermediaries. With online media, the learning process can occur without any regional boundaries and all information can be accessed whenever we want. The purpose of this study is to provide a means for Small, Medium Enterprise (SME) and the community in an effort to increase creativity and innovation through the application of an online learning system. The implementation of this system uses an object-oriented programming approach and evaluation using Blackbox testing.
\end{abstract}

Keywords: Online Learning, Systems, Community

\section{BACKGROUND}

Information technology is growing faster. Most human activities take advantage of the sophistication of information technology for activities, including learning activities that provide general or specific knowledge. The role of communication and information technology in learning today is an inseparable part. Its presence contributes to the development of learning methods for SMEs and society.

The Internet has made online learning possible [1]. people can arrange their own learning time and place freely when they are learning through the network [2]. As a learning method, of course the development process requires a systematic framework. One of the web-based learning development models that can be used is the webbased learning environment development model developed by Hall, Watkins, and Eller [3]. Through this online media, SMEs and the public can share their knowledge such as sharing ideas, experiences and discuss so that can be useful for SMEs and the community.

Small and medium enterprises (SME) from timeto-time experienced significant developments. seen in the data of the Ministry of Cooperatives and SMEs wherein 2017 the number was 62,922,617 and in 2018 the number was 64,194,057 [4]. Various types of products produced from SMEs are of quite good and good quality. Even though these business actors are of the SME level, they consider the quality and quality aspects before the goods they produce will be marketed. Conditions of competitive market competition are an aspect that cannot be separated from attention.

Product diversity and creativity is one of the key forms of business. Many of us find that SMEs are only experts in one field, so their creativity is only what they are good at. For this reason, the development of this application was made to help SMEs acquire new knowledge in order to create diversity and creativity of new products and share knowledge with fellow SMEs and communities and doing discussions.
E-learning is a relatively new term in the world of computer-delivered training and education. e-learning as follows: "any learning, training or education that is facilitated by the use of well-known and proven computer technologies, specifically networks based on Internet technology." E-learning can be classified based on the degree to which it differs from traditional learning strategies. Often it is only one component in a comprehensive learning system that may include such other methods as instructor- led training, self-study, books, videos, and so on. Sometimes this situation occurs when an organization is in transition from traditional learning to e- learning [5].

eLearning platform allows assisted instruction in technical systems, it can solve theoretical problems on their construction, planning, organizing and managing the production and maintenance activities etc., by linking content with practical production training. [6].

\section{METODOLOGY.}

\subsection{Data Collection}

This research applies several data collection techniques that will be used, including: Observation, Interview, literature studies and Documentation. Observations were made by researchers to see references through internet media for the content to be presented and the technology to be implemented. search for literature studies related to system development and learning methods that are suitable for development and secondary data as well as documenting to create content to be filled in in the application. Interviews were conducted with several SMEs and the community regarding the system requirements to be developed. (Table 1).

\subsection{Analysis.}

Developing an online learning system, researchers need data including speaker, UKM or Community and Content. the speaker is someone who provides knowledge in the form of video or text to be used as learning material 
Table 1. Secondary Reference for Reseacher

\begin{tabular}{|c|c|c|c|}
\hline No & Tittle & Author & Information \\
\hline 1 & $\begin{array}{l}\text { A Brief DiscussionAbout the } \\
\text { Accessibility and Usability } \\
\text { of Web- Based Instruction in } \\
\text { Software Design Teaching [2] }\end{array}$ & $\begin{array}{l}\text { Liu Shuai, Glowatz Matt, Zappatore } \\
\text { Marco, Gao Hongha, Jia Bing, Bucciero } \\
\text { Alberto (2018). }\end{array}$ & $\begin{array}{l}\text { Application-based learning tools have been wid } \\
\text { applied. in the learning application the function the } \\
\text { teacher or speaker must have the media as teacher, } \\
\text { evaluator and management of mater online and ensure } \\
\text { that users get or understand t material being taught }\end{array}$ \\
\hline 2 & $\begin{array}{l}\text { Utilization Strategy for E-Learning } \\
\text { based on Resources Sharing for } \\
\text { Development of Human Resources } \\
\text { for SMEs [7] }\end{array}$ & $\begin{array}{l}\text { Sari, Putri Pradnyawidya and Eko, } \\
\text { Bambang Riawan (2019) }\end{array}$ & $\begin{array}{l}\text { Making e-learning designs for SMEs using the } \\
\text { Edmodo cloud application as a learning medium } \\
\text { with a social learning network model }\end{array}$ \\
\hline 3 & $\begin{array}{l}\text { Online learning: Adoption, } \\
\text { continuance, and learning } \\
\text { outcome-A review of literature } \\
{[8]}\end{array}$ & $\begin{array}{l}\text { Panigrahi, Ritanjali. Srivastava, Praveen } \\
\text { Ranjan. Sharma, Dheeraj (2018) }\end{array}$ & $\begin{array}{l}\text { Understanding the application of the e-learning } \\
\text { system in learning is very important to ensure } \\
\text { the successful application of technology and the } \\
\text { continued use of technology is determined on the } \\
\text { basis of experience and satisfaction in the learning } \\
\text { environment provided and the convenience provided. }\end{array}$ \\
\hline
\end{tabular}

Table 2. Analysis Requirement for Systems

\begin{tabular}{|c|c|c|}
\hline No & SME and Community Needs & Requirement \\
\hline 1 & $\begin{array}{l}\text { System user register and } \\
\text { authentication (login system) }\end{array}$ & $\begin{array}{l}\text { - User can register as speaker or users using email address } \\
\text { - Each user has their own username and password according to their access privilege }\end{array}$ \\
\hline 2 & Teaching Material & $\begin{array}{l}\text { - Speaker can upload material (text, video and docs). } \\
\text { - Speakers can edit the material } \\
\text { - Speakers and users can download the material }\end{array}$ \\
\hline 3 & Material fields and categories & $\begin{array}{l}\text { - Speakers can upload material according to their specialization andlevel of proficiency. } \\
\text { - There are several categories of specialization and level of proficiencyto make it easier for } \\
\text { users or presenters to provide teaching materials } \\
\text { - The speaker can publish teaching materials to users or just save it onthe system. }\end{array}$ \\
\hline 4 & List users on system & $\begin{array}{l}\text { - Each speaker and users can see who is registered as a speaker } \\
\text { - Each speaker and users can see who is registered as a user's }\end{array}$ \\
\hline 5 & Discussion & $\begin{array}{l}\text { - Speaker and users can create discussion on the materials } \\
\text { - speakers can provide teaching materials to be commented on by usersand other speakers } \\
\text { - Speakers and users can delete comment in discussion forum. }\end{array}$ \\
\hline 6 & Evaluation & - Speaker can upload assignments and grades electronically \\
\hline 7 & Event & - Speakers can make announcement about events or other information to user \\
\hline 8 & Activities & $\begin{array}{l}\text { - The speaker can create a list of routine activities that the user can Follow } \\
\text { - Users can see the activities that have been assigned by each speaker }\end{array}$ \\
\hline
\end{tabular}

for UKM and society. UKM and the community are the audience who can enjoy the material presented by the speaker and can have discussions. The content delivered can be in the form of video or text to be used as learning and discussion material.

System Design uses process modelling to illustrate the activities undertaken and how data moves between these activities. The way to represent the model process using UML (Unified Modelling Language). The aim of UML is to provide general object-oriented vocabulary and diagramming techniques rich enough to model any systems development project from analysis to implementation [9].

\subsection{Design System.}

System Design uses process modelling to illustrate the activities undertaken and how data moves between these activities. The way to represent the model process using UML (Unified Modelling Language). The aim of UML is to provide general object-oriented vocabulary and diagramming techniques rich enough to model any systems development project from analysis to implementation [10] [9].
An information system cannot be separated from a database or database, a database (or database) is an organized collection of related data in such a way that it is easy to store, manipulate, and invoke by the user [11]. The development of this online learning system uses the Mysql database with the PHP programming language.

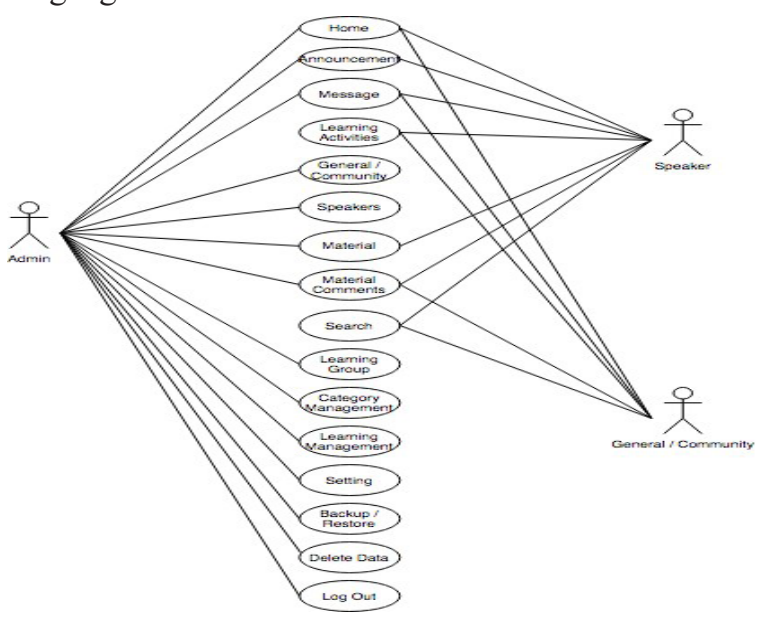

Figure 1: Use Case Diagram E-Learning System 


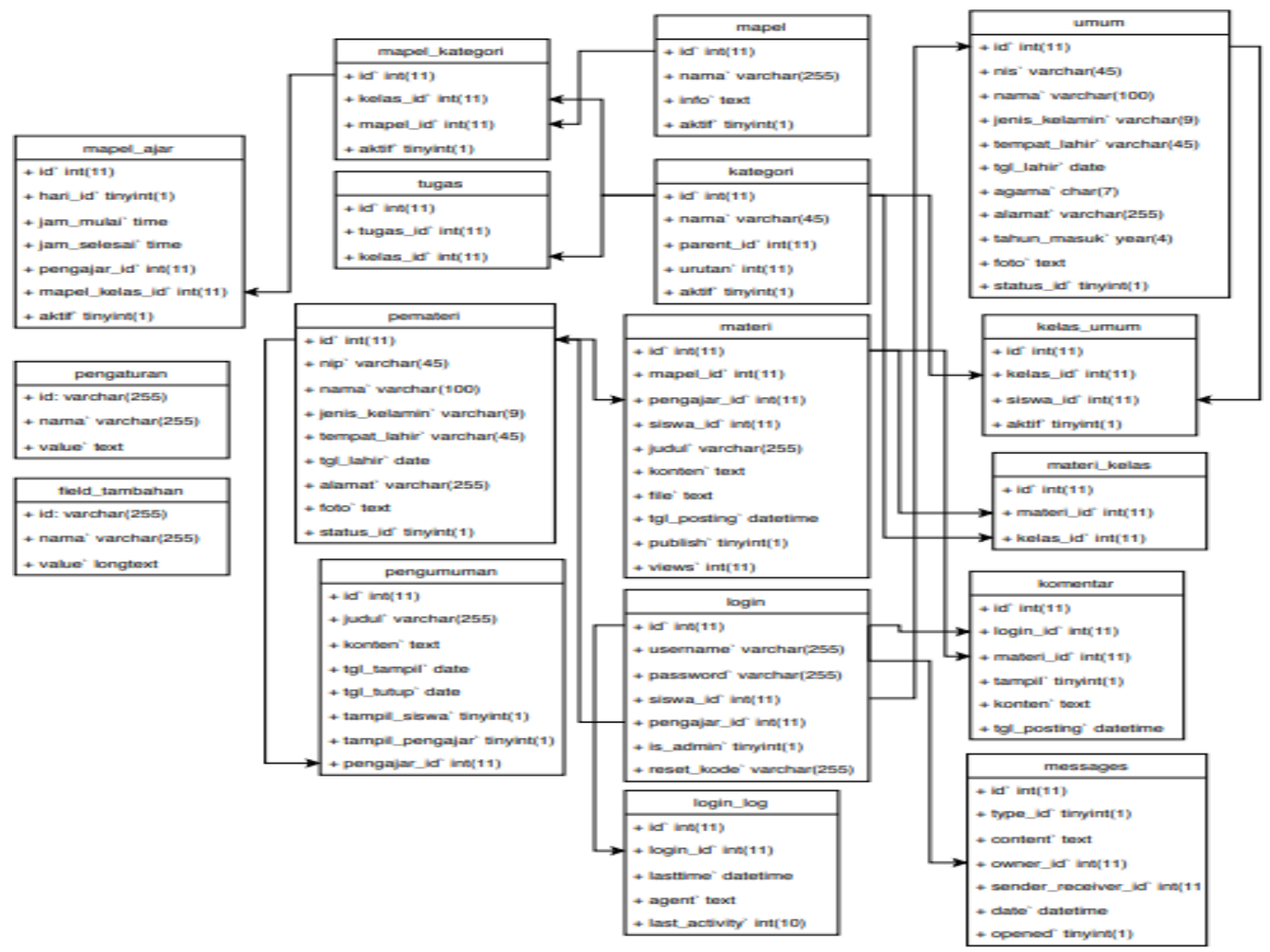

Figure 2: Database E-Learning Systems

Designing components based on previously identified. Starting from the first step is making the Domain model of the system to explain the relationship between entities in a system of e-commerce are made. Based on the need for data and information in the implementation for this research, the tables that are formed are assembled. here's how it looks.

\section{IMPLEMENTATION.}

Figure 3 shows the login page where there is a username and password along with the login and register buttons for new users, both for presenters or SMEs and the community.

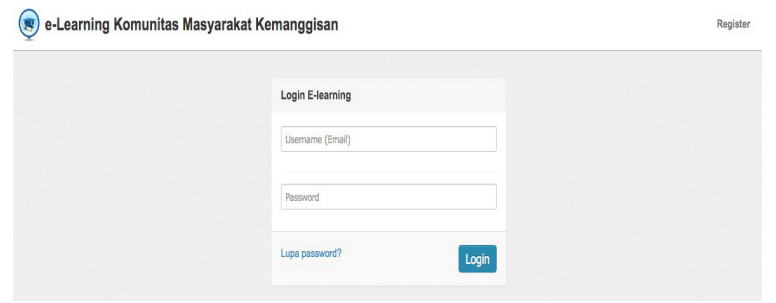

Figure 3. Login Page Views
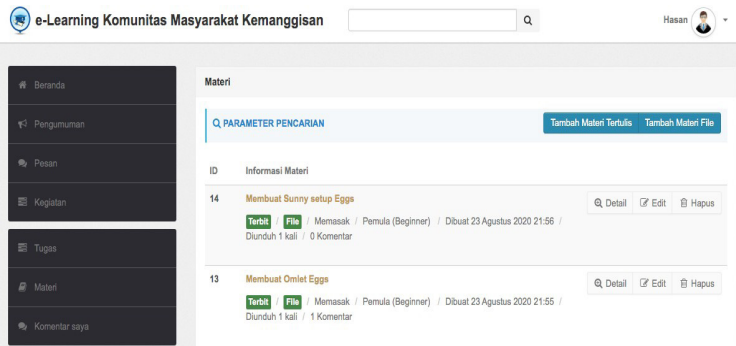

Figure 4. Presenter web page for material list

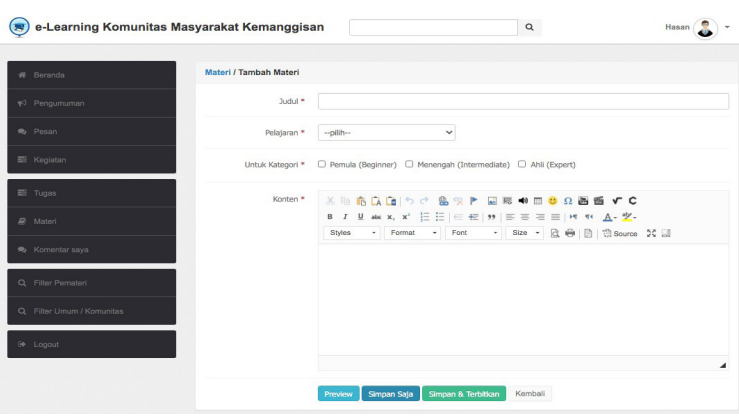

Figure 5. Pages add material for presenters

Figure 4 shows a list of material on the presenter page that has been filled in by the speaker. 5 is web page for presenters to fill material as learning material.

Figure 6 web pages on UKM and the community to see material that can be used as learning that is filled in by the presenters.

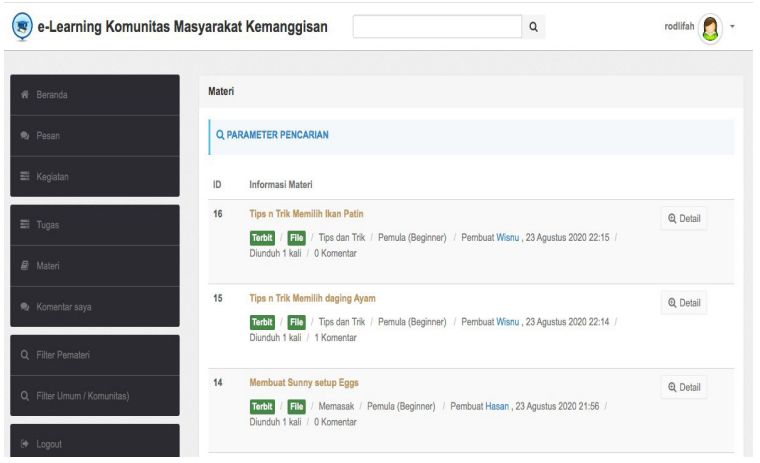

Figure 6. Material listing page in SMEs or 
Communities login Figure 7 web page for presenter registering learning activity time.

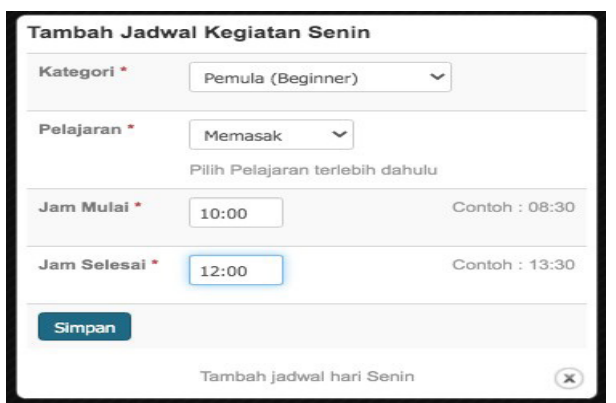

Figure 7. Pages create a schedule for the activities of the presenter

Figure 8 web page on UKM and community to see the activities filled by presenters for learning activities.

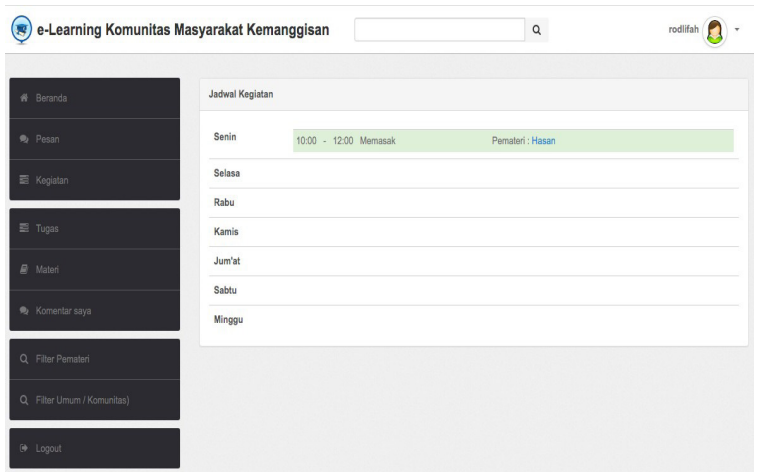

Figure 8. Web page that lists activities for SMEs and the community

Figure 9 web page on the speaker to make announcements that will be disseminated to SMEs and the public

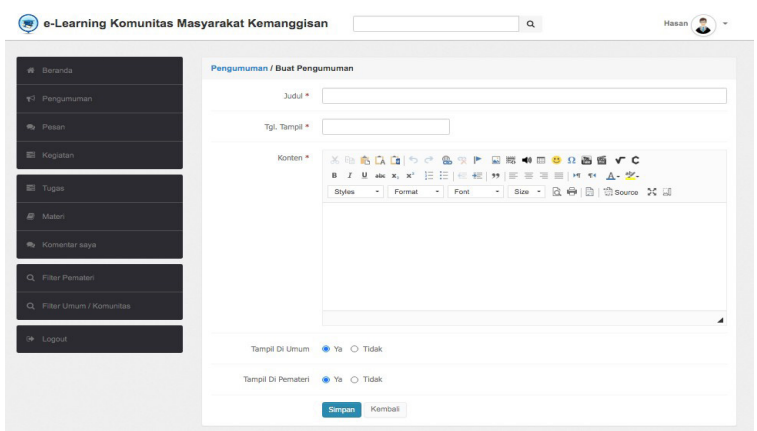

Figure 9. Web page Make announcements on the presenter side

Figure 10 dashboard web page on SMEs and community to view announcements.

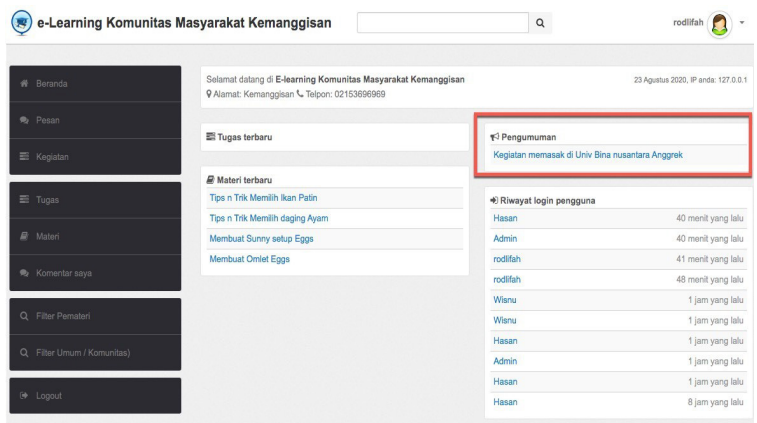

Figure 10. announcement webpage on SMEs and the community

\section{EVALUATION.}

Evaluation on this system is using blackbox testing. Black box testing is a software testing technique used to determine application functionality. The main focus of black box testing is the availability of inputs for the application and the expected outputs for each input value[12].

Table 3. Blackbox Testing

\begin{tabular}{|c|c|c|c|}
\hline No & Testing Material & Testing Purpose & Validation \\
\hline 1 & $\begin{array}{l}\text { Log in with the } \\
\text { registered username } \\
\text { and password }\end{array}$ & $\begin{array}{l}\text { Successful log-in with } \\
\text { registered username and } \\
\text { password) }\end{array}$ & Success \\
\hline 2 & $\begin{array}{l}\text { Login with wrong } \\
\text { username and } \\
\text { password. }\end{array}$ & $\begin{array}{l}\text { Failure to log-in with } \\
\text { incorrect username and } \\
\text { password }\end{array}$ & Success \\
\hline 3 & $\begin{array}{l}\text { Forgot password } \\
\text { feature }\end{array}$ & $\begin{array}{l}\text { Enter the registered } \\
\text { email and the link from } \\
\text { the application sent in } \\
\text { the registered email. }\end{array}$ & Success \\
\hline 4 & $\begin{array}{l}\text { User Register as } \\
\text { speaker oras users }\end{array}$ & $\begin{array}{l}\text { fill all fields or fill only } \\
\text { fields that are marked } \\
\text { with aspecial }\end{array}$ & Success \\
\hline 5 & $\begin{array}{l}\text { Displays all the } \\
\text { features and } \\
\text { differentiator login } \\
\text { as admin, speaker } \\
\text { and users }\end{array}$ & $\begin{array}{l}\text { Each login transfer } \\
\text { using admin, speaker } \\
\text { and general is able to } \\
\text { display a different menu }\end{array}$ & Success \\
\hline 6 & $\begin{array}{l}\text { Displays the } \\
\text { material provided } \\
\text { by the speaker }\end{array}$ & $\begin{array}{l}\text { Can display material } \\
\text { provided by the speaker, } \\
\text { and the speaker's name } \\
\text { and upload time }\end{array}$ & Success \\
\hline 7 & $\begin{array}{l}\text { the speaker can } \\
\text { include discussion } \\
\text { material or } \\
\text { information }\end{array}$ & $\begin{array}{l}\text { Material can upload } \\
\text { using file and text }\end{array}$ & Success \\
\hline 8 & $\begin{array}{l}\text { Speaker and } \\
\text { users can discuss } \\
\text { each other in the } \\
\text { material presented }\end{array}$ & $\begin{array}{l}\text { The discussion between } \\
\text { the presenters and user can } \\
\text { take place in the material } \\
\text { presented at the forum }\end{array}$ & Success \\
\hline 9 & $\begin{array}{l}\text { presenters and } \\
\text { users candiscuss } \\
\text { with each other on } \\
\text { posting material }\end{array}$ & $\begin{array}{l}\text { presenters and users can } \\
\text { provide comments and } \\
\text { delete comments on the } \\
\text { existing discussion forums } \\
\text { on posted material }\end{array}$ & Success \\
\hline 10 & $\begin{array}{l}\text { Speaker can provide } \\
\text { information about } \\
\text { various kinds of } \\
\text { activities through } \\
\text { announcements }\end{array}$ & $\begin{array}{l}\text { Speaker can provide } \\
\text { activity information and } \\
\text { user can see it }\end{array}$ & Success \\
\hline
\end{tabular}

\section{CONCLUSION.}

In carrying out its implementation, E-learning is not merely a transfer of learning on electronic media or internet, but e-learning is a learning process that is poured out through internet technology so that learning can be done anytime and anywhere. Communication in learning needs to be provided like conventional learning so that there will be discussions to share information and knowledge. SMEs and the community can carry out online learning so that it is hoped that it will become a forum for SMEs in creating new product diversity or creativity and for the community to add knowledge about new things and the management of information assets related to knowledge. 
For further research and development, the system can be developed into a mobile application and to deepen appropriate technology, it is necessary to evaluate the community or SMEs before and after participating in this learning activity so that the learning concept becomes effective.

\section{REFERENCES}

[1] T. Nguyen, "The Effectiveness of Online Learning: Beyond No Significant Difference and Future Horizons," MERLOT J. Online Learn. Teach., vol. 11, no. 2, pp. 309-319, 2015.

[2] B. A. Liu Shuai, Glowatz Matt, Zappatore Marco, Gao Hongha, Jia Bing, e-Learning, e-Education, and Online Training, vol. 243, no. April. Cham: Springer International Publishing, 2018.

[3] W. C. Diehl and L. Cano, "Charles A. Wedemeyer and the First Theorists," in Handbook of Distance Education, Fourth edition. | New York: Routledge, 2019. | Previous edition: 2013.: Routledge, 2018, pp. 19-31.

[4] Depkop, "Perkembangan Data Usaha Mikro , Kecil, Menengah Dan Usaha Besar," Www.Depkop.Go.Id, 2018. .

[5] C. Fallon and S. Brown, "Summary for Policymakers," in Climate Change 2013 - The Physical Science Basis, vol. 53, no. 9, Intergovernmental Panel on Climate Change, Ed. Cambridge: Cambridge University Press, 2003, pp. 1-30.

[6] A. Velicanu, I. Lungu, V. Diaconita, and C. Nisioiu, "Advantages to use E-Learning Platform in the Field of Technical Systems," in The International Scientific Conference eLearning and Software for Education, 2017, pp. 121-124.

[7] P. P. Sari and B. R. Eko, "Strategi Pemanfaatan E-Learning berbasis Resource Sharing untuk Pengembangan SDM UMKM," J. Komunika J. Komunikasi, Media dan Inform., vol. 8, no. 2, p. 105, 2019.

[8] R. Panigrahi, P. R. Srivastava, and D. Sharma, "Online learning: Adoption, continuance, and learning outcome-A review of literature," Int. J. Inf. Manage., vol. 43, no. July 2016, pp. 1- 14, 2018.
[9] A. Dennis, B. Wixom, and D. Tegarden, SYSTEMS ANALYSIS \& DESIGN An Object-Oriented Approach with UML, 5th ed. Wiley, 2015.

[10] I. Jacobson, I. Spence, and B. Kerr, "Use-case 2.0: The hub of software development," Queue, vol. 14, no. 1, pp. 94-123, 2016.

[11] A. Nugroho, Perancangan dan implementasi sistem basis data. 2011.

[12] A. Verma, A. Khatana, and S. Chaudhary, "A Comparative Study of Black Box Testing and White Box Testing," Int. J. Comput. Sci. Eng., vol. 5, no. 12, pp. 301-304, 2017.

[13] Almazari, "Web Dokumenary." [Online]. Available: https://www.dokumenary.net/about-me/.

[14] W. G. Moore, M. G., \& Anderson, Handbook of distance education, vol. 41, no. 02. 2003.

[15] W. A. Cidral, T. Oliveira, M. Di Felice, and M. Aparicio, "E-learning success determinants: Brazilian empirical study," Comput. Educ., vol. 122, pp. 273-290, 2018.

[16] H. Junaid, "SUMBER, AZAS DAN LANDASAN PENDIDIKAN (Kajian Fungsionalisasi secara makro dan mikro terhadap rumusan kebijakan pendidikan nasional)," Sulesana, vol. 7, no. 2, pp. 84-102, 2012.

[17] H. Kauffman, "A review of predictive factors of student success in and satisfaction with online learning," Res. Learn. Technol., vol. 23, no. 1063519, pp. 1-13, 2015.

[18] F. A.S and M. Arief, "Pembelajaran Organisasi UKM untuk Menciptakan Keunggulan Bersaing,” J. Ekon. Mod., vol. 13, no. 2, p. 105, 2017.

[19] M. B. Horzum, "Interaction, structure, social presence, and satisfaction in online learning," Eurasia J. Math. Sci. Technol. Educ., vol. 11, no. 3, pp. 505-512, 2015.

[20] P. Dewanti, "Linking national standards of distance education with e-Learning ecosystem," J. Theor. Appl. Inf. Technol., vol. 86, no. 3, pp. 382-393, 2016. 